feelingly as to the disadvantages accruing from such a regulation, which, comparatively speaking, renders the library almost useless as a means of acquiring information, inasmuch as it is impossible for a student to devote much time to reading in the day-time, when lectures and hospital duties demand his more immediate attention, provided even the noise and confusion occasioned by the flowing in and out of idlers would admit of it.

The principals of Guy's Hospital, prior to the October session, never fail in holding forth to the public, in the shape of advertisements, the immense priority their institution claims over others in the extent of its museum, filled with wax models and preparations, together with its extensive library and its advantages. If they really are desirous that the library should possess advantages, I would earnestly suggest to them the propriety of their adopting the same regulations as are observed in the libraries of the London University and others. I am, Sir, your obedient humble servant, $\quad$ M. R. C. S. London, May 28th, 1814.

\section{ATROPINE AND THE SALTS OF ATROPINE.}

\section{To the Editor of ThE LANCET.}

Sin,-In a paper published in ThE LANCET of June 8th, $\mathrm{Mr}$. Cooper recommends a solution of atropine as a substitute for belladonna. The extreme uncertainty attending the use of the extract has been long felt by practitioners. But a primá facie objection may be made to $\mathbf{M r}$. Cooper's solution that it involves the necessity for the addition of spirit of wine. I beg, therefore, to recommend to the profession a trial of the salts of atropine, which are neutral and soluble in distilled water. I am, Sir, your obedient servant, Conduit-street, June 10.

\section{J. Lloyd BuLLock.}

\section{THE SYDENHAM SOCIETY'S TRANSLATION OF} LOUIS' WORK ON PHTHISIS.

\section{To the Editor of THE LANCET.}

SIR,-Will you oblige me by inserting the following brief statement. Yours obediently,

Reading, June 11, 1814.

Charles Cowan, M.D.

It is now nine years since I published and edited, with extensive additions, a translation of "Louis on Phthisis," and in a manner which then elicited the strongest approbation of the periodical press. During the past winter I was asked by some leading members of the Sydenham Society whether it was my intention to print M. Louis' second edition, or whether I would undertake it for the society. In reply I stated, that having to prepare the Retrospective Address, with other engagements, I could not promise to complete a translation before late in the summer, but that if the society was anxious for an earlier period of publication, I should not oppose a selfish barrier to the work being entrusted to any other individual.

In Professor Walshe's translation, just published, not the slightest reference is made to the preceding facts, nor is the existence of an English translation of the first edition even distantly alluded to. Is this just? Is it consistent with either literary or professional courtesy or candour?

THE MEANING OF PRACTICAL PHARMACY.

\section{To the Editor of THE LANCET.}

SrR,-According to the regulations of the Royal College of Surgeons in England, for August, 1839, amended October, 1841, students coming under those regulations are required to produce "a certificate of having studied practical pharmacy for a period of not less than six months." I asked the person who keeps the registration books at the college what was meant by practical phar. macy, but he gave me an evasive answer. He told me to look at the regulations; however, I was none the better for it, as no explanation was given there.

Perhaps you will be kind enough to inform me, through the medium of your Journal, whether a certificate of having dispensed medicines in an apothecary's shop will suffice? I remain, Sir, your most obedient servant,

A Yorkshire Student.

*** The question of our correspondent ought to be answered by the proper authorities for the information of students.

\section{HOUSE OF COMMONS. Tuesday, June 11.}

THE question relating to medical affairs was again postponed. It is now very probable that Sir JAMEs Graham will be enabled to move for leave to introduce the BiLL on Monday next.

\section{NEWS OF THE WEEK.}

Her Majesty has been pleased to confer the honour of knighthood on James Annesley, Esq., of the Madras Medical Establlshment.

We have received from $\mathrm{Mr}$. Freebairn a specimen of his engraving of the Brodie Testimonial Medal. It is most admirably executed, and presents an extremely faithful likeness of the baronet. In the eyes of his numerous friends so faithful a representation of his features must be invaluable.

We last week omitted to mention that Mr. Lonsdale, as well as Mr. Chance, was elected assistant-surgeon to the Orthopodic Institution, two appointments having been made. The poll stood as follows:-Mr. Lonsdale, 155; Mr. Chance, 96 ; Dr. Stubbs, 48.

\section{MORTALITY TABLE.}

THE deaths in the metropolis for the week ending June 8th, were 901. The weekly arerage of the last five years is 946, of the last five winters 1009

Diseases of the lungs .............................. 249

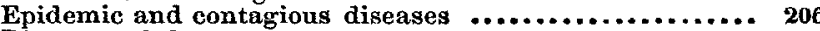

Diseases of the nervous system $\ldots \ldots \ldots \ldots \ldots \ldots \ldots \ldots \ldots, 159$

Dropsy, eancer, and diseases of uncertain seat ......... 11

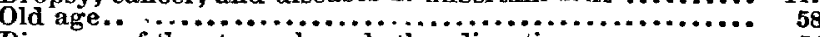

Diseases of the stomach and other digestive organs ...... -56

Diseases of the heart and blood ressels ................ 19

Diseages of the kidneys, \&c. .......................... is

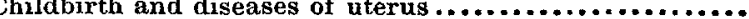

Violence, privation, \&c...

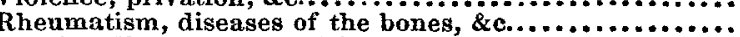

Cellular diseases of the skin $\ldots \ldots \ldots \ldots \ldots \ldots \ldots \ldots \ldots \ldots \ldots$

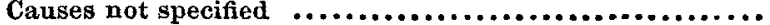

Total.............. 90

ROYAL COLLEGE OF SURGEONS OF ENGLAND.

Lrst of gentlemen admitted members on Friday, June $7,1844:-$ A. Roberts, G. J. Rose, R. C. Griffith, H. J. Domville, H. Buck, J F. Cartner, A. Henfrey, F. W. Marshall, G. P. Hubbard.-Admitted Monday, June 10 :-W.S. Kirkes, H. Semple, H. Holmes, T. Harrison, D. F. Waters, C. D. Arnott, H. L. Pomfret.

\section{APOTHECARIES' HALL, LONDON}

NAMEs of gentlemen who obtained certificates of qualification to practise as apothecaries on Thursday, June 6, $1814:-$ Arthur practise as apothecaries on Thursday, Jume 6, 1814:-Arthur Montgomeryshire; Edward Petch, Atheratone, Warwickshire Montgomeryshire; Edward Petch, Atherstone, Warwickshire; Jun Hard wicke, Dublin ; Winam near Colchester, Essex; Thomas Bell Keetley, Great Grimsby, near Colcheste

\section{BOOKS RECEIVED.}

Statistical Report of One Hundred and Ninety Cases of Insanity admitted into the Retreat, near Leeds. By Samuel Hare, Esq. (Extracted from the Provincial Medical Journal.)

The Transactions of the Provincial Medical and Surgical Association. London: J. Churchill. 1844. 8vo. Pp. 606.

Practical Memoirs on Cutaneous Diseases. By F. Peppercorne. London: J. Churchill. 1844. Pp. 68. On Impending Dissolution and Nervous Affections in Infants. By Rich. Doherty, M.D. (Extracted from the Dublin Journal of Medical Science, March, 1814.

The Chemical Delectus, and Spectacle Secrets. By George Cox. London: Hamilton, Adam, and Co. 1814. 